\title{
Debunking technophobes
}

\section{To the editor:}

Leigh Turner's excellent exposition in the June issue of the similarity of religion to the social belief systems that have build up around biotech (Nat. Biotechnol. 22, 659, 2004) and particularly around the last decade's genomania misses a key point. Technological enthusiasts propounding stem cells (or growth factors, or hormones, or antibiotics - the fads are new, but the promises are not) as the key to defeating the Grim Reaper may answer the same psychological need as promises of heaven or hell. But, unlike religious claims, technological ones can be tested. If I take stem cells and subsequently die, that is rather a letdown for cells as a credo. And it is hard to imagine a company that could keep its investors happy if, after 2,000 years of a phase 3 trial, it still could not produce evidence that would convince a skeptic (that is, the US Food and Drug Administration) that its

'MortaloBust' actually worked.

Of course, popular fantasies, science-fiction films, and the reporters of daily papers paid by the exclamation mark are not so restrained. They do build something that looks like a religious myth system from biotech, something I pointed out over a decade ago ${ }^{1}$. Turner's call for debunkers and skeptics is timely, important and hits the mark. Blurring the line between what is real and what we would like to be real leads at best to a Centoxin (A6H4C5; HA-1A), a Marimastat (BB-2516) or an Erbitux (cetuximab), at worst to deaths of sportspeople taking human growth hormone or erythropoietin.

But we must be wary lest this call gives succor to the technophobes who believe that biotech is blasphemy. Their belief system is as irrational and potentially harmful as that of those peddling immortality through growth hormone injections or buckets of pills. But, unlike the technophiles, whose mutable faith keeps one step ahead of phase 3 failures with the cheery optimism that something will work one day, the technophobe's belief system denies the very data that could make it more moderate. The arguments over genetically modified (GM) crops are illustrative: any data that supports GM crops' safety is decried as flawed, as much on moral as on technical grounds, any data that they might be unsafe, taken as conclusive proof of sacrilege.

There are many regulatory agencies that resist the excesses of selling dreams as reality, some dating from the century before last (for offering people hope when there is none is not a new scam). There are none controlling the scaremongers and political platformbuilders who would set up biotech as the antiChrist of their religious system. I believe it is at these that we should direct the skepticism and debunking. Either that or take the path of one Salk Institute postdoc of some years ago: join the new priesthood and write bestselling novels about people being eaten by cloned dinosaurs or 'grey goo.'

\section{William Bains}

Rufus Scientific, UK

e-mail:william@bains.u-net.com

1. Bains, W. Biotechnology from $A$ to $Z$, edn. 1 , 223-224 (Oxford University Press, Oxford, UK, 1993). 